\title{
Klinik Araştırmalar Mevzuatı: Kısa Bir Güncelleme
}

\author{
Regulations of Clinical Trials: A Brief Update
}

Yusuf ERGÜN

KSÜ Tip Fakültesi Tibbi Farmakoloji ABD, Kahramanmaraş

Geliş tarihi: 09.12.2019 Kabul tarihi: 23.01.2020 DOI: 10.17517/ksutfd.657251

Özet

Türkiye Cumhuriyeti’nde 1993’ten beri klinik araştırmalarla ilgili birçok resmi doküman yayımlanmıştır. Yeni gelişmelere ve ihtiyaçlara cevaben düzenleme makamı bu dokümanları güncellemekte veya yenilerini servis etmektedir. Bu derlemede 1993-2015 yılları arasında çıkarılan düzenlemelerin çok kısa bir özeti sunulduktan sonra 2015-2020 yılları arasında ortaya çıkan önemli yeniliklerden bahsedilecektir. Bu itibarla "Geleneksel ve Tamamlayıcı Tıp Uygulamalarının Klinik Araştırmaları Hakkında Yönetmelik” ve ilişkili dokümanlar mercek altına alınmıştır. Okuyucular klasik klinik araştırmalar dışında kalan bu tip uygulamalarla ilgili önemli bilgilere ulaşacaktır.

Anahtar kelimeler: Klinik araştırmalar; Mevzuat; Yönetmelik; Kılavuz

\begin{abstract}
Several official documents associated with clinical trials have been published since 1993 in the Republic of Turkey. In response to novel developments and needs, the regulatory authority updates these documents or releases new ones. In this review, after presenting a very brief account of the regulations appeared between 1993 and 2015, crucial novelties occurred between 2015 and 2020 will be mentioned.In this context, "By-Law Regarding Clinical Trials of Traditional and Complementary Medicine" and related documents have been scrutinized. The readers will find crucial information about these types of interventions which are beyond classical clinical trials.
\end{abstract}

Key words: Clinical trials; Regulation; By-law; Guideline

Yazışma Adresi: Yusuf ERGÜN Kahramanmaraş Sütçü İmam Üniversitesi, Tip Fakültesi, Tıbbi Farmakoloji Ana Bilim Dalı, Kahramanmaraş, Türkiye Tel: +90 344 3003357,GSM: +90 5325610423 Mail: yusufergun@yahoo.com; yusufergun@ksu.edu.tr

ORCID No: 0000-0002-6169-8911 


\section{GíRiş}

Son birkaç yüzyılda bilimsel arenada ortaya çıkan gelişmeler çok çarpı ı bir nitelikte olmuş ve tıp bilimi de bundan fazlasıyla nasibini almıştır. Özellikle yirminci yüzyllla birlikte hastalıkların tedavisinde beşeri ilaçların rolü giderek artmaya başlamış ve günümüzde yeni ilaç geliştirme çok teknik bir iş haline dönüşmüştür. Yeni bir ilaç icat etmenin çok uzun soluklu, zahmetli ve maliyetli bir süreç olduğu aşikârdır. Binlerce molekül arasından temel araştırmalar ve klinik öncesi hayvan deneylerini aşarak gönüllü insanlar üzerinde denenme hakkını kazanan yeni araştırma ilaçlarının katı bilimsel ve etik normlara uyularak test edilmesi şarttır. Bu amaçla dünyada birçok düzenleyici belge yayımlanmıştır. Buna paralel olarak Türkiye Cumhuriyetỉnde de 1993’den beri çeşitli belgeler düzenleme makamı tarafindan servis edilmiștir ve edilmeye de devam etmektedir. Bu derlemede 1993-2015 ylları arasında çıkarılan düzenlemelerin çok kısa bir özeti sunulduktan sonra 2015-2020 yllları arasında ortaya çוkan önemli yeniliklerden bahsedilecektir. Konuyla ilgili çok daha kapsamlı bilgiye yazarın daha önce yayımladığı iki derlemeden ulaşlabilir $(1,2)$.

\section{2. İlaç ve Biyolojik Ürünlerin Klinik Araştırmaları Hakkında Yönetmelik}

1993 yılında çıkarılan ilk yönetmelik 2008, 2010, 2011 ve 2013 yıllarında güncellenmiştir. 2013 yılındaki son metin ise 2014 ve 2015 yıllarında yapılan düzeltmelerle son halini almış ve "İlaç ve Biyolojik Ürünlerin Klinik Araştırmaları Hakkında Yönetmelik" adı altında klinik araştırmaların ana referansı olmaya devam etmektedir (3-5). Bu yönetmelik dayanağını iki kanundan almaktadır: i) 3359 sayılı kanuna eklenen ek madde 10 (6), ii) Sağlık Bakanlığı ve Bağlı Kuruluşlarının Teşkilat ve Görevleri Hakkında Kanun Hükmünde Kararnamenin 27inci ve 401ncı maddeleri(7).

\section{Tablo I. Sağlık Bakanlığı ile koordinasyon halinde faaliyet gösteren etik kurullar}

Etik kurullar

Klinik Araştırmalar Etik Kurulu (KAREK)

Biyoyararlanım-Biyoeşdeğerlik Çalışmaları Etik Kurulu (BİÇEK)

Kozmetik Araştırmalar Etik Kurulu (KOREK)

Geleneksel ve Tamamlayıcı Tıp Uygulamaları Klinik Araştırmalar Etik Kurulu (GETAK)

Tablo II. Çeşitli etik kurulların onay vermesi gereken araştırma tipleri

Klinik Araştırmalar Etik Kurulu (KAREK) onayı

TİTCK$^{\star}$-Klinik Araştırmalar Dairesi Başkanlığı izni

Ruhsat veya izin alınmış olsa dahi ilaç, tıbbi ve biyolojik ürünler ve bitkisel tıbbi ürünler ${ }^{* *}$ ile yapılacak klinik araştırmalar Gözlemsel ilaç çalışmaları (Retrospektif çalışmalar kapsam dışında)

Tibbi cihaz klinik araştırmaları (+Tıbbi Cihaz Onaylanmış Kuruluş izni)

Gözlemsel tıbbi cihaz çalışmaları (Retrospektif çalışmalar kapsam dışında) (+Tıbbi Cihaz Onaylanmış Kuruluş izni)

Genetik olarak modifiye edilmiş organizma taşıyan ürünler ile hücresel tedaviler veya gen tedavisi içeren ürünler

kullanılarak yürütülecek araştırmalar

İlaç dışı klinik araştırmalar (Tablo III’e bakınız)

Herhangi bir tedavi yöntemi veya araçları ile yapılacak klinik araştırmalar (Kök hücre, organ/doku nakli ve geleneksel ve tamamlayıcı tıp uygulamaları hariç)

Sağlık beyanlı ürünlerin klinik araştırmaları

Biyobenzer ürünler ile yapılacak klinik araştırmalar

Biyoyararlanım-Biyoeşdeğerlik Çalışmaları Etik Kurulu (BİÇEK) onayı

TİTCK-Klinik Araştırmalar Dairesi Başkanlığı izni

Biyoyararlanım ve biyoeşdeğerlik çalışmaları

Kozmetik Araştırmalar Etik Kurulu (KOREK) onayı

TİTCK-Kozmetik Ürünler Dairesi Başkanlığı izni

Kozmetik ürün veya hammaddelerinin etkinlik veya güvenlilik çalışmaları

Kozmetik ürün veya hammaddelerinin klinik araştırmaları

Geleneksel ve Tamamlayıcı Tıp Uygulamaları Klinik Araştırmalar Etik Kurulu (GETAK) onayı

Sağlık Hizmetleri Genel Müdürlüğü İzni

Akupunktur, apiterapi, fitoterapi, hipnoz, sülük uygulaması, homeopati, kayropraktik, kupa uygulaması, larva uygulaması, mezoterapi, proloterapi, osteopati, ozon uygulaması, refleksoloji, müzikterapi

Geleneksel ve Tamamlayıcı Tıp Uygulamaları Yönetmeliği ekinde bulunmayan uygulamalar için İlaç ve Biyolojik Ürünlerin Klinik Araştırmaları Hakkında Yönetmelik kapsamında sadece uygulama merkezlerinde araştırma yapılabilir ve yapılan araştırmaya ilişkin dosyaların bir örneği de Genel Müdürlüğe gönderilir.

*, TİTCK: Türkiye İlaç ve Tıbbi Cihaz Kurumu; *Bitkisel tıbbi ürünler ile yapılan araştırmalar 2019 yılında çıkan yönetmelikle fitoterapi bünyesinde olduğundan “Geleneksel ve Tamamlayıcı Tıp Uygulamaları Klinik Araştırmalar Etik Kurulu” onayına tabiidir. 


\section{Tablo III. İlaç dışı klinik araştırmalar (2010 yılındaki yönetmeliğe göre)}

\section{Klinik Araştırmalar Etik Kurulu (KAREK) onayı}

TİTCK-Klinik Araştırmalar Dairesi Başkanlığı izni

Endüstriyel ileri tıbbi ürünlerle yapılan araştırmalar

Endüstriyel ileri tıbbi ürün: İnsan/hayvan doku ve hücrelerinden kaynaklanan, bir kaynaktan birden fazla insanın

kullanımı için hazırlanan veya bir kişi için hazırlansa dahi içerisinde onaylanmamış endüstriyel ürün/gen tedavi ürünü içeren ileri tıbbi tedavi ürün

Endüstriyel olmayan ileri tıbbi ürünlerle yapılan araştırmalar

Endüstriyel olmayan ileri tıbbi ürün: Bir hastanede ve uzman hekimin sorumluluğunda uygulanabilen, reçeteyle veya hastaya özel sipariş ile hazırlanan, üretiminde bu amaçla kullanım onayı olmayan endüstriyel bir bileşen bulunmayan, sadece o ülke içerisinde kullanılacak olan, özel kalite standartlarına göre hazırlanmış canlı hücresel ürünlerle, otolog dokular

İleri tedavi edici tıbbi ürünlerle yapılan araştırmalar

İleri tedavi tıbbi ürün: Endüstriyel olarak üretilmiş veya endüstriyel işlemlere tabi gen tedavi tıbbi ürünleri, kök/somatik hücre tedavi ürünleri, doku mühendisliği ürünleri ve kombine ileri tedavi tıbbi ürünleri

Tedavi amaçlı denemeler

Bilinen tıbbi müdahale yöntemleri ile tedavisi mümkün olmayan hastalarda veya bu tedavi yöntemlerinin yüksek riskli olduğu durumlarda; bilimsel araştırma sonuçlarının henüz kesin bir nitelik taşımadığı durumlarda dahi hastalığın tedavisi konusunda elde edilmiş somut bazı faydalarından yola çıkılarak, hastanın veya yasal temsilcisinin rızası alınmak suretiyle, uzman hekim tarafından, hastanede yapılan ve bilimsel kurallara uygun olan tedavi

Kök hücre nakli araştırmaları (Sağlık Hizmetleri Genel Müdürlüğü İzni)

Organ/doku nakli araştırmaları (Sağlık Hizmetleri Genel Müdürlüğü İzni)

Genetik materyalle yapılacak araştırmalar

Tibbi cihaz kullanılarak yapılacak araştırmalar

İlaç dışı standart tedavi uygulamaları

Etkililiği ve güvenliliği en az bir adet prospektifrandomize kontrollü çalışmada gösterilmiş ve ScienceCitation Index veya

ScienceCitation Index Expanded kapsamındaki bir dergide yayınlanmak suretiyle kabul edilmiş tedavi

3359 sayılı kanundaki ek madde 10 bu yönetmeliğin kapsamını belirleyici nitelikte olup "Herhangi bir tedavi yöntemi veya araçlarının veyahut ruhsat veya izin alınmıs dahi olsa ilaç ve terkipleri, geleneksel bitkisel tıbbi ürünler ile tıbbi cihazların bilimsel araştırma amacıyla insanlar üzerinde kullanılabilmesi için sağlık bakanlığından izin alınması...” şeklinde ifadeler içermektedir. Buna paralel olarak yönetmelikte biyoyararlanım ve biyoeşdeğerlik çalışmaları da dâhil olmak üzere ruhsat veya izin alınmış olsa dahi insanlar üzerinde yapılacak olan ilaç, tıbbi ve biyolojik ürünler ile bitkisel ürünlerin klinik araştırmalarının kapsam dahilinde olduğu belirtilmiştir. Öte yandan retrospektif çalışmalar yönetmeliğin kapsamı dışında tutulmuştur. Herhangi bir sorumlu araştırmacı bu alanlarda klinik araştırma yapmak istediğinde önce Klinik Araştırmalar Etik Kurulu (KAREK)'ndan onay sonra da Sağlık Bakanlığı'ndan izin almak zorundadır. Ancak biyoyararlanım ve biyoeşdeğerlik çalışmaları onayı Biyoyararlanım-Biyoeşdeğerlik Çalışmaları Etik Kurulu (BİÇEK)'ndanalınmaktadır.

Sağlık Bakanlığı ve Bağlı Kuruluşların Teşkilat ve Görevleri Hakkında Kanun Hükmünde Kararnamenin 27’inci maddesi uyarınca kurulan Türkiye İlaç ve Tibbî Cihaz Kurumu (TİTCK)'na şu ürünler hakkında düzenleme yapma yetkisi verilmiştir: İlaçlar, ilaç üretiminde kullanılan etken ve yardımo maddeler, ulusal ve uluslararası kontrole tabi madde- ler, tıbbî cihazlar, vücut dışı tıbbî tanı cihazları, geleneksel bitkisel tıbbî ürünler, kozmetik ürünler, homeopatik tıbbîürünler ve özel amaçlı diyet gıdalar. Bu bağlamda yönetmelikte kapsam kısmında adı geçmeyen tıbbi cihaz klinik araştırmaları ile gözlemsel tıbbi cihaz çalışmaları "Tıbbi Cihaz Klinik Araştırmaları Yönetmeliği” vasıtasıyla klinik araştırmalar etik kurulunun denetimi altına alınmıștır (8). Benzer olarak kozmetik ürün veya hammaddelerinin etkinlik veya güvenlilik çalışmaları ile kozmetik ürün veya hammaddelerinin klinik araştırmaları "Kozmetik Ürün veya Hammaddelerinin Etkinlik ve Güvenlilik Çalışmaları ile Klinik Araştırmaları Hakkında Yönetmelik” aracılığıyla Kozmetik Araştırmalar Etik Kurulu (KOREK) denetimine bırakılmıştır (9).Yukarıda adı geçen homeopatik tıbbi ürünler dahil olmak üzere geleneksel ve tamamlayıcı tıp uygulamaları ile yapılacak klinik araştırmalar "Geleneksel ve Tamamlayıcı Tip Uygulamalarının Klinik Araştırmaları Hakkında Yönetmelik” kapsamında düzenlenmiştir ve bu tip araştırmalar "Geleneksel ve Tamamlayıcı Tip Uygulamaları Klinik Araştırmalar Etik Kurulu (GETAK) tarafından onaylanmaktadır (Aşağıya bakınız).

Sonuç olarak Sağlık Bakanlığı adına faaliyet gösteren, birbiri ile bağlantısı olmayan toplam dört adet etik kurul bulunmaktadır (Tablo I). Bunlardan ilk üçünün onay vermesi gereken araştırma tipleri Tablo II'de özetlenmiştir. 
Yönetmeliğin kapsam kısmında ya da tanımlar bölümünde belirtilmemiş olsa da ileriki bölümlerde bahsi geçen "genetik olarak modifiye edilmiş organizma taşıyan ürünler ile hücresel tedaviler veya gen tedavisi içeren ürünler kullanılarak yürütülecek araştırmalar" ve "ilaç dışı klinik araştırmalar” da Tablo II’ye KAREK kapsamında olacak şekilde eklenmiştir. Geçmiş yönetmeliklere bakıldığında bu iki tip araştırma hakkında ipuçları bulunmaktadır. 2008 yılında çıkarılan Klinik Araştırmalar Hakkında Yönetmelik’te ilaç dışı klinik araştırmalardan bahsedilmiş ve endüstriyel olmayan ileri tıbbi ürün ile ileri tedavi edici tıbbi ürün bu bağlamda tarif edilmiştir (10). Daha sonra bu yönetmelikte 2010 yılında bir değişiklik yapılarak ilaç dışı klinik araştırmalar tanımlanmıştır (Bakınız Tablo III) (11).

Tablo III'de bahsi geçen "endüstriyel ileri tıbbi ürün, endüstriyel olmayan ileri tıbbi ürün, ileri tedavi tıbbi ürün ve kök hücre" Tablo II'deki “tıbbi ve biyolojik ürünler” kapsamında değerlendirilebilir. Benzer bir şekilde Tablo III'deki "Genetik materyalle yapılacak araştırmalar" da Tablo II'deki "Genetik olarak modifiye edilmiş organizma taşıyan ürünler ile hücresel tedaviler veya gen tedavisi içeren ürünler kullanılarak yürütülecek araştırmalar” ile aşağı yukarı aynı anlama gelmektedir. Son olarak Tablo III'deki "tıbbi cihaz kullanılarak yapılacak araştırmalar” zaten daha ayrıntılı bir şekilde Tablo II'de yer almıştır. Tablo III'de yer alıp Tablo II'de yer almayan, yani güncel yönetmelikte ismi zikredilmeyen, iki başlık "tedavi amaçlı denemeler" ile "ilaç dışı standart tedavi uygulamaları"dır. Bu tip çalışmalar üst norm olan ek madde 10'daki "herhangi bir tedavi yöntemi veya araçları" kapsamında değerlendirilmeli ve KAREK'ten onay alındıktan sonra Sağlık Bakanlığı’ndan izin alınmalıdır. Benzer olarak 2008 (10), 2010 (11) ve 2011 (12) yönetmeliklerinde ayrıca sınıflandırılarak etik kurul onayı ve Kurum iznine tabi kılınmış olan yeni bir cerrahi metot araştırması (hiçbir yönetmelikte ilaç dışı klinik araştırmalar içerisinde değerlendirilmemiştir) güncel yönetmelikte bahsedilmemiş olsa da ek-10'uncu maddedeki kapsayıcı ibare içerisinde değerlendirilmelidir. Tüm bu yönetmeliklerde tanımlanmış araştırma ürünlerinin veya yöntemlerinin dışında kalan, başka bir deyişle herhangi bir yönetmelikte atıf yapılmayan ürünler veya yöntemlerle yap1lan klinik araştırmalar da olabilir. Bu durumlarda araştırma ürünü veya yöntemi ek madde 10'daki "Herhangi bir tedavi yöntemi veya araçları" kapsamında olup olmadığ 1 değerlendirilmeli ve en uygun etik kuruldan onay alındıktan sonra gerekiyorsa Sağlık Bakanlığı’ndan izin alınmalıdır.

KAREK veya BİÇEK kapsamındaki çalışmalarda sorumlu araştırmacı olabilmenin ilk şartı hekim veya diş hekimi olmaktır. Ayrıca sorumlu araştırmacının araştırma konusu ile ilgili dalda uzmanlık veya doktora eğitiminin de tamamlanmış olması gerekmektedir. Öte yandan sorumlu araştırmacının gözetiminde klinik araştırmada hekim olmayan kişiler de araştırmacı olarak yer alabilir. Spesifik olarak, faz I klinik araştırmalarının ve biyoyararlanım-biyoeşdeğerlik çalışmalarının iyi klinik uygulamaları konusunda yeterli eğitim ve deneyime sahip uygun bir ekip ve uzmanlığını veya dokto- rasını yapmış tıp doktoru bir farmakolog tarafından yürütüleceği hükme bağlanmıştır. KOREK denetimine bırakılmış araştırmalarda sorumlu araştırmacının hekim olmasına gerek duyulmamış olup çalışma veya araştırma konusu ile ilgili dalda, çalışma veya araştırmanın gerektirdiği seviyede eğitimini tamamlamış, çalışma veya araştırmanın yürütülmesinden sorumlu olan herhangi bir kişi bu araştırmaları yürütebilir (9).

\section{Geleneksel ve Tamamlayıcı Tip Uygulamalarının Klinik Araştırmaları Hakkında Yönetmelik}

Bu yönetmelik 9 Mart 2019 tarihli ve 30709 sayılı Resmî Gazetede yayımlanarak yürürlüğe girmiş ve önemli bir eksikliği tamamlamıştır (13). Aşağıda bu yönetmeliğin önemli maddeleri özetlenecek ve gerektiğinde yorumlanacaktır.

Birinci Bölümdeki madde 1'e göre yönetmeliğin amac1, "taraf olunan uluslararası anlaşmalar ile iyi klinik uygulamaları çerçevesinde, geleneksel ve tamamlayıcı tıp uygulamaları alanlarında insanlar üzerinde bilimsel araştırma yapılmasına ve gönüllülerin haklarının korunmasına dair usul ve esasları düzenlemek"tir. Kapsam ise madde 2'de açıklanmıştır: Bu yönetmelik insanlar üzerinde yapılacak olan 27/10/2014 tarihli ve 29158 sayılı Resmî Gazetede yayımlanan Geleneksel ve Tamamlayıcı Tıp Uygulamaları Yönetmeliğinde (14) yer alan geleneksel ve tamamlayıcı tıp uygulamalarını klinik araştırmalarını, klinik araştırma yerlerini ve bu araştırmaları gerçekleştirecek gerçek veya tüzel kişileri kapsar(Tablo II). Bu Yönetmelik (14) ekinde bulunmayan uygulamalar için 13/4/2013 tarihli ve 28617 sayılı Resmî Gazete'de yayımlanan İlaç ve Biyolojik Ürünlerin Klinik Araştırmaları Hakkında Yönetmelik (3-5) kapsamında sadece uygulama merkezlerinde (aşağıya bakınız) araştırma yapılabilir ve yapılan araştırmaya ilişkin dosyaların bir örneği de Genel Müdürlüğe gönderilir (Bakınız madde 8/2). Dayanak olarak ise 7/5/1987 tarihli ve 3359 sayılı Sağlık Hizmetleri Temel Kanununun ek 10 uncu maddesi(6) ve 10/7/2018 tarihli ve 30474 sayılı Resmî Gazete'de yayımlanan 1 sayılı Cumhurbaşkanlığı Teşkilatı Hakkında Cumhurbaşkanlığı Kararnamesinin 355 inci maddesinin birinci firkasının ( $\breve{g}$ ) bendi ve 508 inci maddesi işaret edilmiştir (15). Bu bölümde ayrıca tanımlara da yer verilmiştir. Bunlardan önemli olanları aşağıda sıralanmıştır.

Araştırmacı: Sorumlu araştırmacının gözetiminde araştırmacı ekibinde yer alan kişi.

Bakanlık: Sağlık Bakanlığı.

Etik kurul: Gönüllülerin hakları, güvenliği ve esenliğinin korunması amacıyla araştırma ile ilgili konuların yanı sıra gönüllülerin bilgilendirilmesinde kullanılacak yöntem ve belgeler ile bu kişilerden alınacak olurlar hakkında bilimsel ve etik yönden görüş vermek üzere uygulama merkezi bünyesinde kurulacak Geleneksel ve Tamamlayıcı Tip Uygulamaları Klinik Araştırmalar Etik Kurulu (GETAK).

Geleneksel ve tamamlayıcı tıp uygulamalarının klinik araştırmaları: Geleneksel ve tamamlayıcı tıp uygulamaları alanına giren bir veya birden fazla ürünün ve/veya yönte- 
min/yöntemlerin klinik veya farmakolojik etkilerini ortaya çıkarmak ya da doğrulamak, advers olay veya reaksiyonlarını tanımlamak, güvenliliğini ve etkililiğini araştırmak amacıyla insanlar üzerinde yürütülen tüm araştırmalar.

Genel Müdürlük: Sağlık Hizmetleri Genel Müdürlüğü (İzin bu kurumdan alınmaktadır).

Girişimsel olmayan klinik araştırma: Gözlemsel araştırmalar, anket çalışmaları, retrospektif araștırmalar, Geleneksel ve Tamamlayıcı Tip Uygulamaları Yönetmeliğinde belirlenen şartlarda uygulanmaları kaydıyla bir hekim veya diş hekiminin doğrudan ilgilenmesini veya müdahalesini gerektirmeyecek yöntemler kullanılarak yapılacak geleneksel ve tamamlayıcı tıp uygulamaları araştırmaları.

İzin: İyi klinik uygulamaları ve ilgili mevzuata göre belirlenen sınırlar içerisinde araştırmanın ilgili merkezde/merkezlerde gerçekleştirilebileceğine dair Genel Müdürlüğün olumlu kararı.

Sorumlu araştırmacı: Uzmanlık veya doktora eğitimini tamamlamış olup, araştırmanın yürütülmesinden sorumlu olan hekim veya diş hekimi (Sağlık Bakanlığı iznine tabi tüm araştırmalarda, kozmetik ürün veya hammaddeleri ile yürütülenler hariç, sorumlu araştırmacı uzman hekim olmak zorundadir.).

Uygulama: Geleneksel ve Tamamlayıcı Tip Uygulamaları Yönetmeliğinde belirtilen geleneksel ve tamamlayıcı tıp uygulamaları.

Uygulama merkezi: İlgili alanda sertifikası bulunan hekim veya diş hekimi sorumluluğunda Geleneksel ve Tamamlayıcı Tıp Uygulamaları Yönetmeliğinde belirlenen uygulamaları yapmak üzere eğitim ve araştırma hastanesi ve tıp fakültesi veya diş hekimliği fakültesi bulunan üniversitelerin sağlık uygulama ve araştırma merkezi bünyesinde kurulan ve Bakanlıkça yetkilendirilmesi hâlinde eğitim verilebilecek merkez.

Son üç madde dikkate alındığında bir çelişki ortaya çıkmaktadır: Yukarıda sorumlu araştırmacı uzmanlık veya doktora eğitimini almış hekim olarak tanımlanırken uygulama yapmaya yetkili hekimin sertifikalı olması yeterli olmaktadır ki pratisyen hekimler de buna dahildir. Nitekim "Geleneksel ve Tamamlayıcı Tıp Uygulamaları Yönetmeliği”nde sertifikalı tabip "Geleneksel ve tamamlayıcı tıp uygulamaları ile ilgili olarak Bakanlıkça tescil edilmiş sertifikaya sahip tabib” olarak tanımlanmış olup herhangi bir uzmanlık şartı bulunmamaktadır (16). Bu durumda bu nitelikteki hekimlere de sorumlu araştırmacı olma izni verilmelidir.

Araştırmanın genel esasları ikinci bölümdeki madde 5 'te düzenlenmiş olup gönüllüler üzerinde araştırma yapılabilmesi için gereken hususlar "İlaç ve Biyolojik Ürünlerin Klinik Araştırmaları Hakkında Yönetmelik”teki gibidir. Ancak ilk fıkra farklıdır: Araştırmanın, öncelikle insan dışı deney ortamında veya yeterli sayıda deney hayvanı üzerinde yapılmış olması şarttır. Uzun yillar insan üzerinde uygulanan yöntemlerle ilgili yapilacak araştırmalarda, bu bendin birinci cümlesindeki şartın uygulanması etik kurul tarafindan değerlendirilir. Bu son ifadeden anlaşılacağı üzerine ilaç vb. araştırma ürünleri ile yapılan klinik araştırmalarda olmazsa olmaz olan bu şart bu tip çalışmalarda esnetilebilmektedir.

Çocukların, gebeler, lohusalar ve emziren kadınların ve kısıtlıların araştırmaya iştirak etmeleri de "İlaç ve Biyolojik Ürünlerin Klinik Araştırmaları Hakkında Yönetmelik” ile benzerdir.

Üçüncü bölümde bahsi geçen klinik araştırma dönemleri 4 dönem olan ilaç araştırmalarından farklı olarak 2 dönemden ibarettir. İlki, ruhsat veya izin öncesi dönem, araştırma ürününün farmakokinetik özellikleri, toksisitesi, vücut fonksiyonlarına etkisi, terapötik doz sınırları, klinik etkililiği, yeni bir endikasyon araştırması, farklı dozları, yeni veriliş yolları/ yöntemleri, yeni bir hasta popülasyonu veya yeni farmasötik şekilleri yönünden araştırıldı̆̆ı, araştırmanın niteliğine ve mahiyetine göre seçilmiş yeterli sayıda sağlıklı ve/veya hasta gönüllüye uygulanmak suretiyle denendiği dönemdir (Klinik ilaç araştırması faz 1-3 gibi). İkincisi, ruhsat veya izin sonrası dönem, Türkiye'de ruhsat almış ürünlerin onaylanmış endikasyonları, pozoloji ve uygulama şekilleri; izinli ürünlerin ise önerilen kullanımlarına yönelik emniyetinin ve etkililiğinin daha fazla incelenmesi; yerleşik diğer tedavi, ürün veya yöntemlerle karşılaştırılması için gerçekleştirilen klinik araştırma dönemidir (Klinik ilaç araştırması faz 4 ve gözlemsel ilaç araştırması gibi).

Araştırma yapılacak yerler,üzerinde araştırma yapılacak kimselerin emniyetini sağlamaya ve araştırmanın sağlıklı bir şekilde yürütülebilmesine, takibine, gereğinde acil müdahale yapılabilmesine elverişli ve araştırmanın vasfına uygun personel, teçhizat ve laboratuvar imkânlarına sahip olmalıdır. Bakanlığa bağlı eğitim ve araştırma hastanelerinde, üniversite hastanelerinde veya üniversitelere bağlı ve klinik araştırma yapmak üzere tasarlanıp onaylanmış araştırma geliştirme merkezlerinde araştırma yapılabilir. Bu merkezler ve hastanelerde yapılan klinik araştırmalara, gerektiğinde bu merkezlerin ve hastanelerin koordinatörlüğünde veya idarî sorumluluğunda olmak kaydıyla, belirtilen nitelikleri haiz diğer sağlık kurum ve kuruluşları da dâhil edilebilir.

Araştırma başvuru dosyası, İyi Klinik Uygulamaları K1lavuzu ve diğer kılavuzlar çerçevesinde, Genel Müdürlüğün internet sitesindeki başvuru formu ve eklerine göre hazırlanır ve etik kurula ve Genel Müdürlüğe eş zamanlı olarak yapılabilir. Etik kurul onayı, araştırmanın gerçekleştirileceği uygulama merkezi bünyesindeki etik kurul tarafından, burada etik kurul bulunmuyorsa uygulama merkezine en yakın yerdeki etik kuruldan, izin ise Genel Müdürlük tarafından verilir. Çok merkezli klinik araştırmalarda koordinatör merkezin bulunduğu yerdeki etik kuruldan onay alınması, burada etik kurul bulunmuyorsa koordinatör merkeze en yakın yerdeki etik kuruldan onay alınması gerekir. Bu ifadelerden araştırmanın sadece uygulama merkezlerinde yapılabileceği sonucu çıkarılabilir. Ancak bir önceki paragrafta bahsedilen araştırma yapılacak yerler için spesifik olarak uygulama merkezi olması gerektiğine dair bir ifade bulunmadığından 
kapsam daha geniş olarak algılanmaktadır. Bu kafa karıştırıcı durum yönetmelikte yapılacak gerekli güncellemelerle ya da Sağlık Hizmetleri Genel Müdürlüğü tarafından yapılacak duyurularla aydınlatılmalıdır.

Sırasıyla dördüncü, beşinci ve altıncı bölümlerde izah edilen "araştırmaların başlatılması, yürütülmesi, durdurulması ve sonlandırılması", "araştırma ürünleri ile ilgili hükümler ve "bildirimler, araştırma kayıtları, gizlilik ve devir, denetim ve sorumluluk" ile ilgili hükümler "İlaç ve Biyolojik Ürünlerin Klinik Araştırmaları Hakkında Yönetmelik” ile benzerdir.

Yedinci bölümde tanzim edilen etik kurul, gönüllülerin hakları, güvenliği ve esenliğinin korunması amacıyla bu Yönetmelik kapsamındaki araştırmalarla ilgili konuların yanı sıra gönüllülerin bilgilendirilmesinde kullanılacak yöntem ve belgeler ile bu kişilerden alınacak olurlar hakkında bilimsel ve etik yönden değerlendirme yapmak amacıyla, üyelerinin çoğunluğu doktora veya tıpta uzmanlık seviyesinde eğitimli sağlık meslek mensubu olan, en az yedi ve en çok on beş üyeden oluşturulur. Etik kurul, üniversitelerde rektörün, eğitim araştırma hastanelerinde başhekimin önerisi ve Sağlık Hizmetleri Genel Müdürünün onayıla kurulur ve onay tarihi itibarıyla faaliyetlerine başlar. Bu Yönetmeliğin kapsamı içinde kalan konuları değerlendirmek amacıyla, başka kurum veya kuruluşlarca etik kurul veya etik kurul fonksiyonlarını icra edecek ayrı bir kurul veya yapı oluşturulamaz.

Etik kurulda şu nitelikteki üyeler bulunur: a) Varsa, tıp etiği veya tıbbi deontoloji alanında doktora yapmış veya tıpta uzmanlık eğitimi almış kişi, b) Varsa farmakoloji veya farmakognozi alanında doktora veya tıpta uzmanlık eğitimini yapmış kişi, c) Tercihen iyi klinik uygulamaları kurallarına göre düzenlenmiş uluslararası klinik araştırmalara araştırmacı olarak katılmış olan ve tercihen farklı uzmanlık dallarından seçilmiş uzman hekimler, ç) Geleneksel ve tamamlayıcı tıp uygulamaları alanlarının birinde veya birkaçında yetkin olan kişiler, d) Varsa, biyoistatistik alanında veya halk sağl1ğı alanında doktora yapmış veya uzmanlığını almış, tercihen sağlık meslek mensubu kişi, e) Hukuk fakültesi mezunu, tercihen sağlık hukuku, hasta hakları veya klinik araştırmalar gibi alanlarda tecrübe sahibi kişi, f) Sağlik meslek mensubu olmayan kişi.

Etik kurulun çalışma usul ve esasları ile görev ve yetkileri "İlaç ve Biyolojik Ürünlerin Klinik Araştırmaları Hakkında Yönetmelik” ile benzerdir.

Etik kurul onayına itiraz ile ilgili madde şu şekildedir: İlaç ve Biyolojik Ürünlerin Klinik Araştırmaları Hakkında Yönetmelikte belirtilen ve Türkiye İlaç ve Tibbi Cihaz Kurumu nezdinde teşkil olunan Klinik Araştırmalar Danışma Kurulu, Genel Müdürlüğün talebi durumunda, bu Yönetmelik hükümlerine tabi tüm klinik araştırmalarda etik kurul onaylarına yapılacak itirazlar ve klinik araştırmanın taraflarınca Türkiye İlaç ve Tibbi Cihaz Kurumuna iletilen ve uzmanlık görüşü gerektiren hususlarda görüş bildirir.

Gönüllülerin klinik araştırmadan doğabilecek zararlara karşı güvence altına alınması amacıyla, bu Yönetmelik kapsamındaki araştırmalara katılacak gönüllüler için klinik araştırma sigortası yaptırmak zorunludur. Ancak, bazı klinik araştırmalar, bu araştırmaların gönüllüye getirebileceği bir risk bulunmaması veya riskin kabul edilebilir bir düzeyde olması sebebiyle sigorta kapsamı dışındadır. Sigorta kapsamına alınan veya sigorta kapsamı dışında tutulan klinik araştırmalar aşağıda belirtilmiştir:

a) Girişimsel olmayan klinik araştırmalar sigorta kapsamı dışındadır (Yukarıya bakınız).

b) Geleneksel ve Tamamlayıcı Tıp Uygulamaları Yönetmeliğinde belirtilen uygulamalarda ve şartlarda yapılmaları şartıyla geleneksel ve tamamlayıcı tıp uygulamalarının araç ve yöntemleri ile yapılacak klinik araştırmalar sigorta kapsamı dışındadır. Ancak, etik kurul ve/veya Genel Müdürlük, gerekçesini belirtmek şartıyla bu bentte belirtilen araştırmalar için de sigorta yapılmasını isteyebilir.

c) Türkiye İlaç ve Tibbi Cihaz Kurumunun ruhsatlandırdığı veya izin verdiği beşeri tıbbi ürün, geleneksel bitkisel tıbbi ürün, bitkisel ürün, tıbbi cihaz, kozmetik ürün veya homeopatik ürünlerle yapılacak geleneksel ve tamamlayıcı tıp uygulamalarının klinik araştırmaları, bu ürünlerin ruhsatlarındaki endikasyonlarda, dozlarda ve popülasyonlarda yapılması şartıyla sigorta kapsamı dışındadır, aksi takdirde sigorta yaptırılması zorunludur.

ç) Sağlık kurum veya kuruluşlarında rutin olarak yapılan kan, idrar, tükürük ve benzeri materyalin alınması işlemleri sigorta kapsamı dışındadır.

d) Bu fikrada sayılanlar haricinde kalan ve klinik araştırma sırasında gönüllüler üzerinde yapılabilecek diğer tüm muayene, teşhis, tetkik, profilaksi ve tedavi yöntemlerinde gönüllülerin sigortalanmasıyla ilgili uyulacak hususlar Genel Müdürlüğün hazırlayacağı bir kılavuzla düzenlenir.

\section{Sağlık Bakanlığı İznine Tabi olmayan Araştırmalar}

Yukarıdaki çeşitli yönetmeliklerde bahsi geçen ve ilgili etik kurullardan onay alındıktan sonra Sağlık Bakanlığı’nın izni ile yürütülebilecek olan araştırma tiplerinden farklı olan birçok araştırma tipi daha bulunmaktadır. Bu tip araştırmalar için araştırmanın yapılacağı kurumda teşkil edilen, Sağlık Bakanlığı’ndan bağımsız etik kurullardan onay ve izin alınması yeterlidir. Araştırmanın yapılacağı kurumda etik kurul yoksa en yakın yerdeki etik kuruldan onay ve izin alınır. Bu tip etik kurullara birçok üniversitede "girişimsel olmayan araştırmalar etik kurulu" adı verilmektedir ki bu isim tercihi çok da doğru değildir. Çünkü girişimsel olmayan (yani gözlemsel) ilaç ve tıbbi cihaz araştırmaları da Sağlık Bakanlığı iznine tabidir. Onu yerine sadece "Fakülte Etik Kurulu" veya Amerika Birleşik Devletleri ekolünden hareketle "Kurumsal Değerlendirme Kurulu (Institutional Review Board)" adı kullanılabilir. Avrupa birliğinde "Etik Kurul" tabiri kullanılırken Amerika Birleşik Devletleri’nde "Kurumsal Değerlendirme Kurulu" tercih edilmekte olup ikisi de aynı şeydir. Öte yandan, istenildiği takdirde KAREK de Sağlık Bakanlığ iznine tabi olmayan araştırmaları inceleyebilir ve onay vere- 
bilir. Ancak bu karma/tek etik kurul modelinin (KAREK=KAREK+Fakülte Etik Kurulu/Kurumsal Değerlendirme Kurulu) avantajları olduğu kadar dezavantajları da vardır. En önemli avantajı tüm araştırma tiplerinin tek bir kurul tarafından incelenmesi ve böylece bürokratik iş yükü (sekreterlik işleri, standart operasyon prosedürleri vs.) için gereken personel ve zamanın azaltılması ve standardizasyonudur. Ayrıca klinik farmakoloji uzmanı olan hekim kökenli deneyimli bir Tibbi Farmakoloji uzmanının KAREK’teki zorunlu varlığ yapılacak hataların önüne geçilmesi için bir fırsattır. KAREK ve Fakülte Etik Kurulu/Kurumsal Değerlendirme Kurulu ayrı olarak oluşturulduğunda ortaya çıkan bir risk Sağlık Bakanlığı iznine tabi araştırmaların yanlışlıkla Fakülte Etik Kurulu/ Kurumsal Değerlendirme Kurulu'nda değerlendirilmesidir. Öte yandan özellikle perifer üniversite hastanelerine çok fazla Sağlık Bakanlığı iznine tabi araştırma gelmediğinden buradaki etik kurullar genellikle Sağlık Bakanlığı iznine tabi olmayan araştırmalarla ilgilenmektedir. KAREK’teki farmakolog gibi zorunlu bir üyenin kaybı KAREK'in bir süre askıya alınmasına ve Sağlık Bakanlığı iznine tabi olmayan araştırmaların değerlendirilmesinde gereksiz aksamalara yol açabilir. KAREK ve Fakülte Etik Kurulu/Kurumsal Değerlendirme Kurulu'nun ayrı olarak yapılandırılması tercih edildiğinde başvurusu yapılan araştırmaların tipinin tayini için hekim kökenli tıbbi farmakoloji uzmanının ön-incelemede bulunmasıya da her iki etik kurulda da görev alması faydalı olabilir.
Sağlık Bakanlığ olduğu ile ilgili olarak geçmiş yönetmeliklerde açıklamalar yapılmıştır. Bu itibarla 2010 yılındaki yönetmelik yol göstericidir (Bakınız Tablo IV). Ayrıca "Geleneksel ve Tamamlayıcı Tıp Uygulamalarının Klinik Araştırmaları Hakkında Yönetmelik"in tanımlar kısmında da "girişimsel olmayan klinik araştırma” adı altında benzer bir açıklayıcı tanımlama bulunmaktadır (Bakınız Tablo IV). Bu araştırmaların ortak özelliği araştırma ürünü veya yönteminin veya araştırmanın amac1 ile ilgili yapılan işlemlerin, insana doğrudan müdahale gerektirmemesidir. Benzer bir şekilde Kurumun internet sitesinde de "Araştırmaya dahil olan gönüllünün hastalığı için aldiğ tedaviyi değiştirmemek veya etkilememek, araştırmaya dahil olan gönüllüler sağlıklı bireyler ise yeni bir tedavi vermemek veya uygulama yapmamak kaydı ile tanımlamaya yönelik olarak yapılan kök hücre, kan, saç, tüy, tükürük, gaita, idrar, doku, radyolojik görüntü, biyokimya, mikrobiyoloji, patoloji materyalleri üzerinde yapılacak araştırmalar, vücut fizyolojisi ile ilgili araştırmalar, hücre veya doku kültürü araştırmaları, antropometrik ölçümlere dayalı yapılan araştırmalar, anket ve benzeri bilgi toplama araçları ile yapılan araştırmalar ve yaşam alışkanlıklarının değerlendirilmesi çalışmaları gibi insana doğrudan müdahale gerektirmeden yapılacak çalışmalar üniversitelerde senato kararı ile kurulan etik kurullarca (Fakülte Etik Kurulu/Kurumsal Değerlendirme Kurulu gibi isimlendirilebilecek) değerlendirilir” denmektedir (17).

\section{Tablo IV. Sağlık Bakanlığı İznine Tabi Olmayan Araştırmalar}

Klinik Araştırmalar Yönetmeliğinde tarif edilen (2010 yılı)

Anket çalışmaları

Dosya ve görüntü kayıtları kullanılarak yapılan retrospektif arşiv taramaları ve benzeri gibi gözlemsel çalışmalar ile kan, idrar, doku, görüntü gibi biyokimya, mikrobiyoloji, patoloji ve radyoloji koleksiyon materyalleriyle veya rutin tetkik ve tedavi işlemleri sırasında elde edilmiş materyallerle yapılacak çalışmalar

Hücre veya doku kültürü çalışmaları

Hemşirelik faaliyetlerinin sınırları içerisinde yapılacak araştırmalar

Egzersiz gibi vücut fizyolojisi ile ilgili araştırmalar

Antropometrik ölçümlere dayalı yapılan çalışmalar

Yaşam alışkanlıklarının değerlendirilmesi araştırmaları

İnsana bir hekimin doğrudan müdahalesini gerektirmeden yapılacak tüm araştırmalar

TİTCK internet sitesinde tarif edilen

Anket ve benzeri bilgi toplama araçları ile yapılan araştırmalar

Tanımlamaya yönelik olarak yapılan kök hücre, kan, saç, tüy, tükürük, gaita, idrar, doku, radyolojik görüntü, biyokimya, mikrobiyoloji, patoloji materyalleri üzerinde yapılacak araştırmalar

Hücre veya doku kültürü araştırmaları

Vücut fizyolojisi ile ilgili araştırmalar

Antropometrik ölçümlere dayalı yapılan araştırmalar

Yaşam alışkanlıklarının değerlendirilmesi

Geleneksel ve Tamamlayıcı Tıp Uygulamalarının Klinik Araştırmaları Hakkında Yönetmelik’te tarif edilen (2019)

Gözlemsel araştırmalar

Anket çalışmaları

Retrospektif araştırmalar

Geleneksel ve Tamamlayıcı Tıp Uygulamaları Yönetmeliğinde belirlenen şartlarda uygulanmaları kaydıyla bir hekim veya diş hekiminin doğrudan ilgilenmesini veya müdahalesini gerektirmeyecek yöntemler kullanılarak yapılacak geleneksel ve tamamlayıcı tıp uygulamaları araştırmaları 
Araştırmanın tipi, yani sağlık Bakanlığ 1 iznine tabi olup olmaması, sorumlu araştırmacının niteliğini de doğrudan etkilemektedir. Yukarıda işaret edildiği üzere KAREK, BIÇEK ve GETAK kapsamındaki araştırmalarda sorumlu araştırmac1 hekim veya diş hekimi olmak zorundadır. Diğer taraftan Sağlık Bakanlığı iznine tabi olmayan çalışmalarda sorumlu araştırmacının hekim olması zorunlu mudur? İnsana doğrudan müdahale yapılmayan çalışma olduğunda zorunlu değildir (17). Bir araştırma ürünü olarak bir ilacı, bir tıbbi cihazı veya bir geleneksel veya tamamlayıcı tıp uygulamasını gönüllüler üzerinde bunların etkililiğini veya güvenliliğini araştırmak amacıyla vermek ve üstelik araştırmayı prospektif müdahaleli (girişimsel, deneysel, invaziv) tasarımla yapmak (prospektif veya enine kesitli gözlemsel ilaç/tıbbi cihaz çalışması da dahil) hekimin doğrudan müdahalesini gerektiren bir durum olduğundan hekim olmayanlar sorumlu araştırmacı olamaz. Kan almak için damara girmek şeklindeki invaziv bir müdahale bu anlamda bir müdahale değildir ve bu durumda ekibe, çalışma için kan alınıyorsa, kan alma yetkisi olan bir sağlık meslek mensubu (yardımcı) araştırmacı olarak eklenmelidir. Aksine, rutin tanı için zaten alınan kandan birtakım parametreler ölçülecekse bu anlamda bir yardımcı araştırmacıya gerek yoktur. Burada bahsi geçen "doğrudan müdahale" özetle araştırma ürünü/yöntemi ile ilişkilidir. Yani araştırmanın odağındaki hipoteze konu olan işlem referans noktasıdır ve müdahale olarak kast edilen odur.

Peki insana doğrudan müdahale yapılmayan çalışmaların bazılarında etik kurullar sorumlu araştırmacının hekim olmasını şart koşabilir mi? Aslında yönetmelikte KAREK'e araştırmacıların uygunluğunu sorgulama ve araştırmada görev alan araştırma ekibinin araştırmanın niteliğine göre uygunluğuna karar verme yetkisi verilmiştir (3-5) ve bu prensip tüm etik kurullara, Fakülte Etik Kurulu/Kurumsal Değerlendirme Kurulu dahil, uygulanmalıdır. Bu itibarla bazı Sağlık Bakanlı̆̆ı iznine tabi olmayan ve insana doğrudan müdahale gerektirmeyen araştırmalarda etik kurul hekim olma şartı arayabilir. İnsana doğrudan hekim müdahalesi gerektirmeyen bir çalışmada, aslında, sorumlu araştırmacı araştırma konusu ile ilgili konuda uzmanlık veya doktora eğitimini tamamlamış olmak zorunda olduğundan, bazı durumlarda sorumlu araştırmacının hekim olması gerekebilir. Bunun takdiri etik kurulda olsa da başvuruyu yapan sorumlu araştırmacı Sağlık Bakanlı̆̆ı’ndaki Klinik Araştırmalar Danışma Kurulu'na itiraz edebilir. Zira bu kurulun görevleri şöyle tanımlanmıştır: i) Klinik araştırmalarla ilgili olarak etik kurullarca tereddüt edilen ve sadece Kuruma yazılı olarak görüş almak üzere iletilen hususlarda bilimsel ve teknik yönden görüş bildirmek, ii) gönüllüler ve araştırmanın taraflarınca klinik araştırmalarla ilgili tereddüt edilen ve sadece Kuruma yazılı olarak görüş almak üzere iletilen hususlarda görüş bildirmek (3-5).

Sonuç olarak sorumlu araştırmacının hangi nitelikte olması gerektiğinin anlaşılması için ardışık kritik sorular sorulmalıdır: (i) Araştırma SaXğlık Bakanlığı iznine mi tabidir? Cevap evet ise, sorumlu araştırmacı hekim olmak zorundadır. Ancak kozmetik ürünlerle yapılan araştırmalarda böyle bir şart yoktur.

(ii) İnsana doğrudan müdahale söz konusu mudur? Cevap evet ise, sorumlu araştırmacı hekim olmalıdır (Kozmetik hariç).

(iii) İnsana doğrudan müdahale ile ilgili soruya yanıt hayır ise, "araştırma konusu uzmanlığı hekim olmayı gerektirmekte midir" diye sorgulanmalıdır. Cevap evet ise, hekim olmalıdır. Hayır ise, hekim olmasına gerek yoktur.

Her ne kadar güncel yönetmelikte bahsedilmese de, Sağlık Bakanlığı iznine tabi olmayan araştırmalar içinde 2010 yılındaki yönetmelikte tanımlanan "Hemşirelik faaliyetlerinin sınırları içerisinde yapılacak araştırmalar" üzerinde ayrıca durulması gereken bir konudur. Hemşirelik Kanunu ve Hemşirelik Yönetmeliği ile hemşirelik faaliyetleri tanımlanmıştır $(18,19)$. Bu çerçevede yapılacak araştırmalar için Sağlık Bakanlığı'ndan izin almak gerekmemektedir. Her ne kadar hemşirelik eğitim programı içerisinde pek yer almasa da, dünyada tamamlayıcı ve alternatif tedavilerin hemşirelik faaliyetlerinde giderek daha fazla oranda yer almaya başladığı da bir gerçektir. Bu yöntemlerden en çok kullanılanlar masaj, aküpresür, reflekseloji, yoga, reiki ve aromaterapidir $(20,21)$. Bu yöntemleri konu alan ve müdahaleli (girişimsel) tasarımla yapılan randomize kontrollü klinik araştırmalar dünyada yapılmaktadır. Ülkemizde de hemşirelik ile ilgili lisansüstü eğitimlerin artması ile birlikte uzman hemşirelerin sayısı artmaya başlamış, dahiliye hemşireliği ve cerrahi hemşireliği gibi ana bilim dalları kurulmuş ve dolayısıyla bu tip akademik araştırmaların önü açılmıştır. Örneğin aküpresör ile prospektif, randomize kontrollü bir çalışma uzman bir hemşire tarafından etik kurulların önüne getirildiği zaman ne yapılması gerekir? Araştırma Sağlık Bakanlığı izni gerektirir mi gerektirmez mi? Uzman hemşire sorumlu araştırmacı olabilir mi?

Geleneksel ve Tamamlayıcı Tıp Uygulamalarının Klinik Araştırmaları Hakkında Yönetmelik içerisinde tanımlanıp sertifikalı tabiplerin yetkili kılındığı yöntemler bir kenara bırakılırsa, geriye kalan bazı geleneksel ve tamamlayıcı tedavilerin "Hemşirelik faaliyetlerinin sınırları içerisinde yapılacak araştırmalar" veya "Sağlık Bakanlığı iznine tabi araştırmalar" kategorilerinden birine sokulması gerekir. Yukarıda da işaret edildiği üzere, Geleneksel ve Tamamlayıcı Tıp Uygulamaları Yönetmeliği (14) ekinde bulunmayan uygulamalar için (masaj, aküpresür, reflekseloji, yoga, reiki ve aromaterapi gibi) İlaç ve Biyolojik Ürünlerin Klinik Araştırmaları Hakkında Yönetmelik (3-5) kapsamında sadece uygulama merkezlerinde araştırma yapılabileceği belirtilmiş olduğundan bu tip araştırmalar, mevcut mevzuat çerçevesinde, ikinci kategoriye dahil edilmektedir. Üstelik bu uygulamalar Ek 10 maddedeki "herhangi bir tedavi yöntemi veya araçları" ibaresi kapsamı içine de sokulabilir ki bu durumda hem Sağlık Bakanlığı izni gerekir hem de tedavi yetkisi hekimlerde olduğundan so- 
rumlu araștırmacı hekim olmak zorunda olur. Bu durumda hemşirelerin uyguladığı bir tedavi yönteminin (insana doğrudan müdahale) bir hekim sorumluluğunda araştırılması gibi paradoksik bir durum ortaya çıkar. Bu araştırma yapmak isteyen akademideki hemşirelerin hekime bağımlı olması sonucunu doğurur. Bu nedenle en kısa sürede düzenleyici otorite tarafından uzman hemşirelerin sorumluluğunda yapılabilecek müdahalelerin ve bununla ilişkili araştırmaların niteliğini aydınlatan resmi belgeler yayımlanmalıdır.

\section{SONUÇ}

1993-2015 yılları arasında birçok kanun, yönetmelik vb. resmi belge yayınlanarak başta klinik araştırmalar olmak üzere insanlar veya onlardan elde edilen materyaller üzerinde yapılan bilimsel araştırmalar düzenlenmeye çalışılmıştır. Geldiğimiz noktada, eksikler olsa da, önemli oranda sağlıklı bir sistem oluşturulmuştur. Son olarak son 5 yılda çıkan "Geleneksel ve Tamamlayıcı Tıp Uygulamaları Yönetmeliği” ve "Geleneksel ve Tamamlayıc Tip Uygulamalarının Klinik Araştırmaları Hakkında Yönetmelik” önemli bir eksikliği tamamlamıştır. Etik kurulları ister tek ister ayrı oluşturulsun, en çok zorlayan takip edilmesi gereken mevzuatın hacmi ve teknik detaylarıdır. Bu durum araştırma tiplerinin tayininde, onay ve izin süreçlerinde ve sorumlu araştırmacının niteliğinin saptanmasında hatalar yol açmaktadır. Bu nedenle bu tip kurullarda klinik farmakoloji çok iyi bilen ve deneyimli hekim tıbbi farmakoloji uzmanlarının bulundurulması kaçınilmazdir.

\section{KAYNAKLAR}

1. Ergün Y. Klinik Araştırmalar: Türkiye’deki Mevzuatın Kronolojisi. Arşiv Kaynak Tarama Dergisi 2017: 26(3); 378-426.

2. Ergün Y. Klinik Araştırmalar: Türkiye’deki Güncel Mevzuatın Bir Özeti. KSÜ Tip Fak Der 2017: 12(1); 50-72.

3. Klinik Araştırmalar Hakkında Yönetmelik. Resmi Gazete yayım tarihi: 13/04/2013; Say1: 28617.

4. Klinik Araştırmalar Hakkında Yönetmelikte Değişiklik Yapılmasına Dair Yönetmelik. Resmi Gazete yayım tarihi: 25/06/2014; Say1: 29041.

5. İlaç ve Biyolojik Ürünlerin Klinik Araştırmaları Hakkında Yönetmelikte Değişiklik Yapılmasına Dair Yönetmelik. Resmi Gazete yayım tarihi: 13/09/2015; Sayı: 29474.

6. 3359 sayılı Sağlık Hizmetleri Temel Kanunu kanuna eklenen ek madde 10. Kabul tarihi: 06/04/2011; Kanun no: 6225.

7. Sağlık Bakanlığı ve Bağlı Kuruluşlarının Teşkilat ve Görevleri Hakkında Kanun Hükmünde Kararname. Resmi Gazete yayım tarihi: 02/11/2011; Say1: 28103.

8. Tıbbi Cihaz Klinik Araştırmaları Yönetmeliği. Resmi Gazete yayım tarihi: 06/09/2014; Sayı: 29111.

9. Kozmetik Ürün veya Hammaddelerinin Etkinlik ve Güvenlilik Çalışmaları ile Klinik Araştırmaları Hakkında Yönetmelik. Resmi Gazete yayım tarihi: 20/09/2015; Say1: 29481.

10. Klinik Araştırmalar Hakkında Yönetmelik. Resmi Gazete yayım tarihi: 23/12/2008; Sayı: 27089

11. Klinik Araştırmalar Hakkında Yönetmelikte Değişiklik Yapılmasına Dair Yönetmelik. Resmi Gazete yayım tarihi: 11/03/2010; Say1: 27518.
12. Klinik Araştırmalar Hakkında Yönetmelik. Resmi Gazete yayım tarihi: 19/09/2011; Sayı: 28030.

13. Geleneksel ve Tamamlayıcı Tip Uygulamalarının Klinik Araştırmaları Hakkında Yönetmelik. 09/03/2019; Sayı: 30709.

14. Geleneksel ve Tamamlayıcı Tip Uygulamaları Yönetmeliği. Resmi Gazete yayım tarihi: 27/10/2014; Sayı: 29158.

15. 1 sayılı Cumhurbaşkanlığı Teşkilatı Hakkında Cumhurbaşkanlığı Kararnamesi. Resmi Gazete yayım tarihi: 10/07/2018; Sayı: 30474.

16. Geleneksel ve Tamamlayıcı Tip Uygulamaları Yönetmeliği. Resmi Gazete yayım tarihi: 27/10/2014; Sayı: 29158.

17. http://www.titck.gov.tr/Dosyalar/Ilac/KlinikArastirmalar/KlinikArastirmalarSSS.pdf

18. Hemşirelik Kanunu. Resmi Gazete yayım tarihi: 02/03/1954; Say1: 8647.

19. Hemşirelik Yönetmeliği. Resmi Gazete yayım tarihi: 08/03/2010; Say1: 27515.

20. Buchan S, Shakeel M, Trinidade A, Buchan D, Ah-See K. Theuse of complementary and alternativ emedicine by nurses. Br J Nurs. 2012 Jun 14-27;21(11):672-4.

21. Fowler S, Newton L. Complementary and alternative therapies: the nurse's role. J Neurosci Nurs. 2006 Aug;38(4):261-4. 